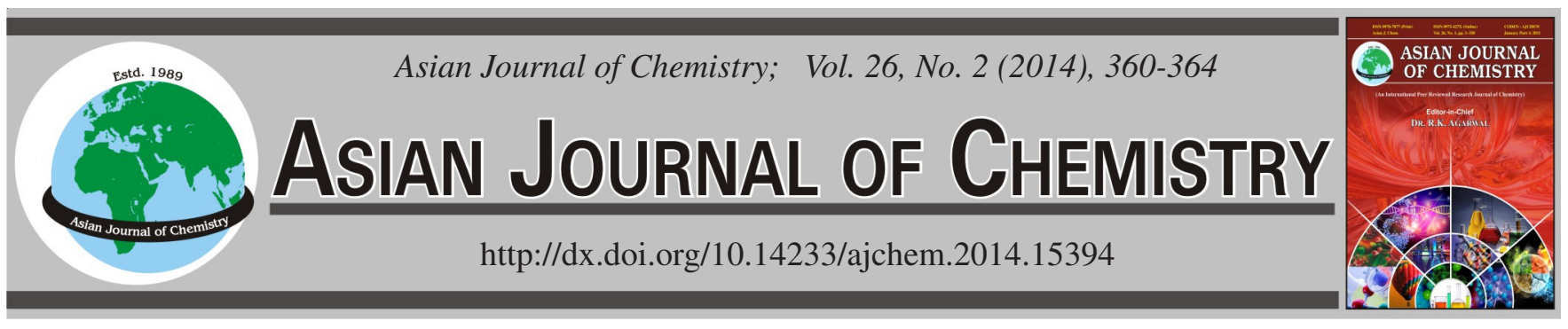

\title{
Proximate Composition and Minerals Profile of Fruit and Flower of Karir (Capparis decidua) from Different Regions of Punjab (Pakistan)
}

Amna Iqbal ${ }^{1}$, Faroog Anwar $^{2, *}$, Raziya Nadeem $^{1, *}$, Bushra Sultana $^{1}$ and Muhammad Mushtaq ${ }^{1}$

${ }^{1}$ Department of Chemistry and Biochemistry, University of Agriculture, Faisalabad-38040, Pakistan

${ }^{2}$ Department of Chemistry, University of Sargodha, Sargodha-40100, Pakistan

*Corresponding authors: E-mail: fqanwar@yahoo.com; raziyanalyst@yahoo.com

Received: 27 February 2013;

Accepted: 27 May 2013;

Published online: 15 January 2014;

AJC-14543

\begin{abstract}
The present work appraises the proximate composition and minerals profile of flower and fruit of Capparis decidua from three different regions of Punjab, Pakistan. The percentage of moisture, ash, fibre and protein in flower and fruit of $C$. decidua from Jhang, Layyah and Sarghodha of Punjab was found to be 58.3-73.11, 55.4-70.31, 4.9-7.8, 3.9-5.4, 15.03-16.64, 16.27-19.41, 21.88-23.75 and 24.06-33.90 \%, respectively. Overall, the contents of protein, fibre and ash were found to be higher in the samples of flower and fruit of Layyah while lowest in Sargodha region. On the other hand, the concentration of P, Mn and Fe were higher in the samples of fruit and flower from Jhang region whereas $\mathrm{Na}, \mathrm{Ca}, \mathrm{Cu}$ and $\mathrm{K}$ were higher in Layyah region while the samples from Sargodha exhibited lowest amount of minerals. These present results indicated that the flower and fruit of $C$. decidua analyzed from different regions, although having considerably different contribution of proximate parameters and minerals, can be explored as a potential source of valuable nutrients.
\end{abstract}

Keywords: Capparis decidua, Fruit and flower, Protein, Fibre, Wet digestion, Minerals, Atomic absorption spectrometry.

\section{INTRODUCTION}

Nature has blessed us with diversity of medicinal plants which are in use as a source of food and traditional medicine since the history of mankind due to the presence of valuable nutrients and therapeutic agents ${ }^{1-3}$. According to World Health Organization (WHO), around $80 \%$ of population from developed and under developed countries still relay on plant based traditional medicine for the cure of different ailments. The medicinal plants are the best sources to obtain a variety of newer herbal drugs ${ }^{4-6}$.

In view of the current developments in the field of functional foods and nutraceuticals, now there is a revival of interest in the use of plants as a source of food and medicine. Many of the plant species have medicinal value besides having nutritional significance. Plant nutrients such as carbohydrates, lipids and proteins play an important role in catering human energy needs while other plant bioactives such as antioxidants and polyphenols impart various physiological benefits .

With regard to the human health, the role of minerals cannot be overlooked as they activate enzymes, hormones and other organic molecules that participate in the growth, functioning and maintenance of several life processes. Some micro minerals or trace elements (zinc, iron, copper and manganese) not only play an important role in enzymatic catalysis, but also have vital role in several biochemical and physiological processes and are known to be essential for good health ${ }^{8-10}$.

Capparis decidua, belonging to the family Capparidaceae and locally named as 'Kari' or 'Karir', is drought resistant plant. The plant is widely distributed in dry and desert areas of Punjab, Pakistan. In Cholistan, the floral buds are cooked as delicious vegetables; pickles formed by green berries and ripened seeds are boiled with water, dried and preserved to be used later as vegetable. The young twigs serve as fodder for cattle and goats $^{11,12}$.

Almost all parts $C$. decidua plant have been used for traditional medicinal and therapeutic applications including treatment of tooth ache, arthritis, asthma, alleviate cholera, dysentery, urinary purulent discharges, cardiac problems, constipation, hysteria, cough, soreness, intermittent fevers, malaria, rheumatism and puffiness ${ }^{12-14}$.

The review of scientific data available regarding the medicinal importance of $C$. decidua and recent divergence of scientific interest towards exploration of natural resources as a source of food and medicine motivated us to appraise and compare the proximate parameters and minerals profile of fruits and flowers of $C$. decidua collected from different regions of Punjab, Pakistan. 


\section{EXPERIMENTAL}

The fruit and flower of $C$. decidua were collected from Jhang, Layyah and Sarghodha regions of Punjab, Pakistan. The specimens were further identified and authenticated by Department of Botany, University of Agriculture Faisalabad, Pakistan

Pretreatments of samples: The samples of fruit and flower of $C$. decidua were washed with distilled water, dried under ambient conditions for several days till complete dryness and finally ground into a fine powder for further experimental uses.

Proximate analysis: The proximate analysis of fruits and flowers of $C$. decidua was carried out in the laboratories of Department of Animal Nutrition, University of Agriculture, Faisalabad according to the Official Methods of the Association of Official Analytical Chemists (AOAC) with slight changes ${ }^{15}$.

Moisture content: For determination of moisture, accurately weighed $(5 \mathrm{~g})$ of the fruit and flower material of $C$. decidua was taken in Petri dishes and dried in hot oven (Memmet $\mathrm{GmbH}, \mathrm{D}-91126$, Germany) at $100{ }^{\circ} \mathrm{C}$ till constant weight achieved $^{15}$.

$$
\text { Moisture }(\%)=\frac{\text { Moisture loss }(\mathrm{g})}{\text { Weight of original sample }(\mathrm{g})} \times 100
$$

Ash content: For ash content estimation, $1 \mathrm{~g}$ of sample material, placed in crucible, was combusted in a Muffle Furnace; TMF-2100 (AYELA) at $500{ }^{\circ} \mathrm{C}$. The percentage ash content was calculated using the formula ${ }^{15}$ :

$$
\text { Ash }(\%)=\frac{\text { Weight of ash }(\mathrm{g})}{\text { Weight of original sample }(\mathrm{g})} \times 100
$$

Crude fiber contents: A weighed quantity of dried and de-fated sample $(3 \mathrm{~g})$ was digested using $250 \mathrm{~mL}$ of $0.12 \mathrm{~N}$ $\mathrm{H}_{2} \mathrm{SO}_{4}$ for $0.5 \mathrm{~h}$ and filtered. Theresidue was washed several times with distilled water until all the acid soluble components were removed. The residues were now boiled with 250 $\mathrm{mL}$ of $0.313 \mathrm{~N} \mathrm{NaOH}$ for half an hour to remove alkali soluble components. After filtration, the residues were dried, weighed and ignited in a Muffle Furnace, TMF-2100 (AYELA) till conversion into $\operatorname{ash}^{15}$. The percentage of crude fiber was calculated as:

$$
\text { Crude fiber }(\%)=\frac{\text { Weight loss on ignition }(\mathrm{g})}{\text { Weight of original sample }(\mathrm{g})} \times 100
$$

Protein contents: Protein contents of fruits and flowers of $C$. decidua were determined using Kjeldahl apparatus ${ }^{15}$. Briefly, $3 \mathrm{~g}$ of dried sample was mixed with digestion mixture (copper sulphate, ferric sulphate and potassium sulphate by the ratio of 9:1:90), added $10 \mathrm{~mL}$ of conc. $\mathrm{H}_{2} \mathrm{SO}_{4}$, digested for 1-2 $\mathrm{h}$ till solution become clear. Now, diluted the mixture with distilled water to make the volume of the solution up to 250 $\mathrm{mL}$. About $10 \mathrm{~mL}$ of this solution were mixed with $10 \mathrm{~mL}$ of $40 \% \mathrm{NaOH}$ and $10 \mathrm{~mL}$ of distilled water and transferred to distillation chamber, where $5 \mathrm{~mL}$ of $2 \%$ boric acid and few drops of methyl red as an indicator were added.

The distillate obtained was titrated with $0.12 \mathrm{~N} \mathrm{H}_{2} \mathrm{SO}_{4}$ until yellow to pink colour change observed. The crude protein contents were evaluated as:

$$
\begin{gathered}
\mathrm{N}(\%)=\frac{\text { Vol. of } 0.12 \mathrm{~N} \mathrm{H}_{2} \mathrm{SO}_{4} \text { used } \times \text { Vol. of dilution } \times 0.0014}{\text { Weight of samples }(\mathrm{g}) \times \text { Vol. of diluted solution used }} \times 100 \\
\text { Crude protein }(\%)=\text { Nitrogen }(\%) \times 6.25
\end{gathered}
$$

Minerals profile: The minerals composition of the samples under investigation was determined in Bio-analytical research laboratory of the Department of Chemistry and Biochemistry, University of Agriculture, Faisalabad using the method described earlier ${ }^{16}$. Accurately weighed $1 \mathrm{~g}$ of each sample material was separately treated with $10 \mathrm{~mL}$ of conc. $\mathrm{HNO}_{3}$ in a beaker and subjected to heating at $70-80{ }^{\circ} \mathrm{C}$ for 1 to $2 \mathrm{~h}$. The temperature was then raised to $150{ }^{\circ} \mathrm{C}$ and heating continued. During this second phase of heating, added further 3-5 mL of conc. $\mathrm{H}_{2} \mathrm{SO}_{4}$ and 3-5 $\mathrm{mL}$ of $\mathrm{H}_{2} \mathrm{O}_{2}$ occasionally and wet digestion continued until transparent solution obtained. After the digestion process completed, the contents of beaker were cooled, diluted with $10 \mathrm{~mL}$ of deionized water, filtered through Whatman filter paper \# 42 and the solution finally made upto $100 \mathrm{~mL}$ with deionized water.

Calcium, manganese, iron, zinc, copper, calcium and phosphorous were analyzed using atomic absorption spectrophotometer (Hitachi Polarized Zeeman AAS, Z-820. Japan) whereas sodium and potassium were analyzed by flame photometer (410 Sherwood Flame Photometer) ${ }^{16}$.

\section{RESULTS AND DISCUSSION}

Proximate composition: Proximate analysis is the description of proximate composition and nutritive value of foods and feeds ${ }^{17}$. Protein, fiber and minerals are essential to life.The present work deals with the estimation of moisture, ash, crude fiber and crude protein contents of two parts (flower and fruit) of $C$. decidua harvested from three different regions of Punjab, Pakistan.

Moisture content: The moisture content of flowers and fruits of $C$. decidua from different regions (Jhang, Layyah and Sarghodha) ranged from 58.3 to 73.11 and 55.40 to $70.31 \%$, respectively showing significant variation $(p<0.05)$ among the regions selected (Table-1). The moisture in flower from Jhang (70.31 to 73.11) was higher than Sarghodha (55.40$60.71 \%)$ and Layyah (56.12-58.30\%). When compared between the two parts of C.decidua, there was found no significant difference of the moisture content between the flower and fruit tested $(p>0.05)$.

Furthermore, the average moisture content in C. decidua determined in the present study $(62.32 \%)$ was found to be lower than that reported by Dahot ${ }^{18}$ who determined $73.40 \%$ mean moisture content from Sindh.

Ash: Ash contents of flower and fruit of C. decidua from different regions of Punjab were determined on the dried weight basis and the results reproted as mean \pm SD of triplicate experiments (Table-1).

The value of ash in the flower and fruits of $C$. decidua from three regions (Jhang, Layyah and Sarghodha) of Punjab was found to be 4.90-7.80 and 3.90-5.40\%, respectively. The ash contents of flowers and fruits Layyah region was significantly $(p<0.05)$ higher $(7.8$ and $5.4 \%)$ as compared to Sarghodha and Jhang regions. The higher contents of ash in Layyah samples could be supported by the minerals levels of the samples in this region (Table-2). The range of ash content 


\begin{tabular}{|c|c|c|c|c|}
\hline \multirow{3}{*}{ Proximate parameters } & \multicolumn{3}{|c|}{$\begin{array}{c}\text { TABLE-1 } \\
\text { COMPARISON OF PROXIMATE COMPOSITION OF FLOWER AND } \\
\text { FRUIT OF } C \text {. decidua FROM DIFFERENT REGIONS OF PUNJAB }\end{array}$} & \\
\hline & \multirow{2}{*}{ Plant part } & \multicolumn{3}{|c|}{ Regions } \\
\hline & & Jhang & Layyah & Sargodha \\
\hline \multirow{2}{*}{ Moisture (\%) } & Flower & $73.11 \pm 0.02^{\mathrm{c}}$ & $58.31 \pm 0.05^{\mathrm{a}}$ & $60.70 \pm 0.13^{\mathrm{a}}$ \\
\hline & Fruit & $70.31 \pm 0.12^{\mathrm{c}}$ & $56.10 \pm 0.04^{\mathrm{a}}$ & $55.41 \pm 0.22^{\mathrm{a}}$ \\
\hline \multirow{2}{*}{ Ash (\%) } & Flower & $4.90 \pm 0.27^{\mathrm{a}}$ & $7.80 \pm 0.06^{c}$ & $6.50 \pm 0.13^{\mathrm{b}}$ \\
\hline & Fruit & $3.90 \pm 0.09^{\mathrm{a}}$ & $5.40 \pm 0.12^{\mathrm{c}}$ & $4.20 \pm 0.15^{\mathrm{b}}$ \\
\hline \multirow{2}{*}{ Crude fiber (\%) } & Flower & $15.03 \pm 0.14^{\mathrm{a}}$ & $16.64 \pm 0.03^{c}$ & $15.95 \pm 0.13^{b}$ \\
\hline & Fruit & $16.27 \pm 0.15^{\mathrm{a}}$ & $19.41 \pm 0.04^{\mathrm{c}}$ & $17.52 \pm 0.09^{b}$ \\
\hline \multirow{2}{*}{ Protein $(\%)$} & Flower & $21.89 \pm 0.02^{\mathrm{b}}$ & $23.75 \pm 0.03^{\mathrm{b}}$ & $22.74 \pm 0.14^{\mathrm{b}}$ \\
\hline & Fruit & $24.06 \pm 0.15^{\mathrm{a}}$ & $33.90 \pm 0.02^{\mathrm{c}}$ & $26.26 \pm 0.08^{\mathrm{a}}$ \\
\hline
\end{tabular}

Values are mean \pm SD of triplicate measurements. Means with different superscript letters show significant $(p<0.05)$ difference among regions.

\begin{tabular}{|c|c|c|c|c|}
\hline \multicolumn{5}{|c|}{$\begin{array}{l}\text { TABLE-2 } \\
\text { COMPARISON OF MINERALS CONTENT (mg/100 g) IN FLOWER AND } \\
\text { FRUIT OF } C \text {. deciduafrom FROM DIFFERENT REGIONS OF PUNJAB }\end{array}$} \\
\hline Contents (mg/100 g dry weight) & Plant part & Jhang & Layyah & Sarghodha \\
\hline \multirow{2}{*}{ Sodium } & Flowers & $180.15 \pm 7.22^{c}$ & $190.21 \pm 7.15^{\mathrm{c}}$ & $40.02 \pm 1.63^{\mathrm{a}}$ \\
\hline & Fruits & $120.32 \pm 4.03^{\mathrm{b}}$ & $150.15 \pm 6.02^{c}$ & $60.08 \pm 2.12^{\mathrm{a}}$ \\
\hline \multirow{2}{*}{ Potassium } & Flowers & $230.00 \pm 11.25^{\mathrm{c}}$ & $237.00 \pm 9.20^{c}$ & $80.04 \pm 3.21^{\mathrm{a}}$ \\
\hline & Fruits & $440.25 \pm 17.65^{\mathrm{c}}$ & $480.36 \pm 19.2^{c}$ & $140.21 \pm 7.25^{\mathrm{a}}$ \\
\hline \multirow{2}{*}{ Manganese } & Flowers & $0.35 \pm 0.01^{\mathrm{b}}$ & $0.34 \pm 0.01^{\mathrm{a}}$ & $0.33 \pm 0.17^{\mathrm{a}}$ \\
\hline & Fruits & $0.11 \pm 0.01^{\mathrm{b}}$ & $0.10 \pm 0.00^{\mathrm{b}}$ & $0.12 \pm 0.00^{\mathrm{b}}$ \\
\hline \multirow{2}{*}{ Copper } & Flowers & $1.22 \pm 0.03^{\mathrm{b}}$ & $1.91 \pm 0.07^{\mathrm{c}}$ & $0.69 \pm 0.02^{\mathrm{a}}$ \\
\hline & Fruits & $1.83 \pm 0.03^{\mathrm{b}}$ & $2.10 \pm 0.084^{c}$ & $0.90 \pm 0.04^{\mathrm{a}}$ \\
\hline \multirow{2}{*}{ Calcium } & Flowers & $20.10 \pm 0.31^{\mathrm{b}}$ & $32.91 \pm 1.36^{c}$ & $13.30 \pm 0.56^{\mathrm{a}}$ \\
\hline & Fruits & $21.50 \pm 0.45^{\mathrm{b}}$ & $35.10 \pm 1.46^{\mathrm{c}}$ & $15.20 \pm 0.60^{\mathrm{a}}$ \\
\hline \multirow{2}{*}{ Iron } & Flowers & $76.11 \pm 3.20^{c}$ & $70.32 \pm 2.15^{\mathrm{a}}$ & $67.91 \pm 2.75^{\mathrm{a}}$ \\
\hline & Fruits & $17.32 \pm 0.64^{c}$ & $15.60 \pm 0.63^{c}$ & $12.30 \pm 0.44^{\mathrm{a}}$ \\
\hline \multirow{2}{*}{ Zinc } & Flowers & $0.27 \pm 0.01^{\mathrm{b}}$ & $0.25 \pm 0.01^{\mathrm{b}}$ & $0.22 \pm 0.00^{\mathrm{a}}$ \\
\hline & Fruits & $0.23 \pm 0.00^{c}$ & $0.20 \pm 0.10^{c}$ & $0.17 \pm 0.00^{\mathrm{a}}$ \\
\hline \multirow{2}{*}{ Phosphorous } & Flowers & $550.23 \pm 22.20^{c}$ & $484 \pm 19.15^{b}$ & $426 \pm 17.04^{\mathrm{a}}$ \\
\hline & Fruits & $807.52 \pm 32.34^{c}$ & $790 \pm 31.38^{c}$ & $701 \pm 28.44^{\mathrm{a}}$ \\
\hline
\end{tabular}

(3.9-7.8\%) in the flowers and fruit as determined in the present work was found to be higher as comparable to those $(3.03$ and $0.87 \%$ ) as reported by Haq et al. ${ }^{19}$ and Chinedu et al. ${ }^{20}$, respectively.

Crude fiber: The value of crude fiber in the flower and fruit of $C$. decidua from three different regions (Jhang, Layyah and Sarghodha) of Punjab was found to be 15.03-16.64 and 16.27-19.41\%, respectively. The contents of fibre in flowers and fruits of Layyah region were significantly $(p<0.05)$ higher (16.64 and $19.41 \%$ ) than those from other two regions studied.

The present investigation demonstrated that the content of crude fiber was considreably lower than that (10.44\%) reported by Haq et al. ${ }^{19}$.

Protein: The amount of crude protein in flower and fruits of $C$. decidua from different regions of Punjab as given in Table-1 was noted to be 21.88-23.75 and 24.06-33.90\%, respectively. The overall region based variation of protein content in flower and fruit of $C$. deciduawasfound to be: Layyah sampels $>$ Sarghodha samples $>$ Jhang samples that might be attributed to the variable agroclimatic and geographical conditions of the these regions.

Furthermore, the average crude protein in the two parts of $C$. decidua $(25.4 \%)$ determined presently was found to be quite comparable to another food plant i.e. Moringa $(23.6 \%)$ reported by Jongrungruangchok et al. ${ }^{21}$ and C. decidua (27.71 $\%)$ reported by Haq et al. ${ }^{19}$.
Minerals profile: Sodium, plays an important role as electrolyte, regulates the osmotic pressure, transmits nerve impulse, relaxes muscles and maintains a proper water balance within the body ${ }^{9-10,22-23}$. The results regarding sodium content in fruits and flowersof $C$. decidua from different geological zones of punjab (Jhang, Layyah and Sarghodha) ranged from 40-190 and 60-150 mg/100 g, respectively (Table-2). The statistical analysis also revealed that the sodium contents of the samples tested varied significantly among different regions of Punjab $(p<0.05)$ which might be attributed to variable soil and enviromental conditions of the areas. Furthermore, the average content $(115 \mathrm{mg} / 100 \mathrm{~g})$ of sodium in the two parts as determined in the present work was found to be lower as comparable to that $(130 \mathrm{mg} / 100 \mathrm{~g})$ investigated by Vyas et al $^{24}$.

Potassium regulates the volume of blood and maintains the balance of fluid, transmits nerve impulse, controls heart action and metabolism of carbohydrate and protein. Table-2 indicates the average potassium content in flower and fruit of C. decidua from different regions of Punjab to be 80-237 and $140-480 \mathrm{mg} / 100 \mathrm{~g}$, respectively. The variation $(p<0.05)$ in potassium content of flower and fruit of $C$. decidua samples from Jhang, Layyah and Sarghodha might be attributed to difference in soil compostion and agroclimatic conditions. The average content $(267 \mathrm{mg} / 100 \mathrm{~g})$ of potassium of two parts as established in the present work was found to be lower as compared to those reported by Vyas et $a .^{24}$. 
Manganese plays role in blood breakdown of amino acids and production of energy, metabolism of vitamin $\mathrm{B}_{1}$ and vitamin $\mathrm{E}$ and activation of various enzymes ${ }^{9,25}$. Hence, deficiency symptoms may results in paralysis, dizziness, loss of hearing, aging, digestive problems, blindness and deafness in infants ${ }^{26}$. The average manganese content in the flower and fruits of C. decidua from three different regions (Jhang, Layyah and Sarghodha) of Punjab was found to be 0.33-0.35 and 0.10$0.11 \mathrm{mg} / 100 \mathrm{~g}$, respectively.

The contents of manganese of flowers and fruits of Jhang region was significantly $(p<0.05)$ higher $(0.35$ and $0.11 \mathrm{mg} /$ $100 \mathrm{~g}$ ) as compared to Layyah and Sarghodha regions, while the Sarghodha region showed lowest content $(0.33$ and 0.10 $\mathrm{mg} / 100 \mathrm{~g})$ of manganese. The average content $(0.22 \mathrm{mg} / 100$ g) of manganese as determined in the present work was found to be very low and negligible in amountas compared with that reported by Vyas et al. ${ }^{24}$.

The Food and Nutrition Board estimates that safe and adequate daily intake of dietary copper is $1.5-3.0 \mathrm{mg}$ for adults ( $1 \mathrm{mg}$ of copper is $1 \mu \mathrm{mol})$. Copper deficiency elevates cholesterol, blood pressure, uric acid and has adverse effects, impairs glucose tolerance, promotes thrombosis to which male respond differently than females. Copper helps in conversion of iron into hemoglobin and oxidizes vitamin C. It is also an integral part of certain digestive enzymes. Deficiency of copper may result in general weakness, anemia impaired respiration, skin soreness ${ }^{22,27,28}$. The copper contents in the flower and fruits of C. decidua from three different regions (Jhang, Layyah and Sarghodha) of Punjab varied between 0.69-1.91 and 0.90-2.10 $\mathrm{mg} / 100 \mathrm{~g}$, respectively with higher levels $(1.91$ and $2.10 \mathrm{mg}$ / $100 \mathrm{~g}$ ) in Layyah samples as compared to Jhang and Sarghodha regions. Further, the average content $(1.44 \mathrm{mg} / 100 \mathrm{~g})$ of C. decidua found in the present work was noted to be lower as compared to those $(2.04 \mathrm{mg} / 100 \mathrm{~g})$ reported by Vyas et al. ${ }^{23}$.

Calcium regulates many cellular processes and is essential for structural maintenance of body ${ }^{26,29}$. The results for calcium contents observed in fruits and flowers of $C$. deciduafrom different zones of Punjab, Pakistan ranged from 13.3 to 32.9 and 15.2 to $35.1 \mathrm{mg} / 100 \mathrm{~g}$, respectively (Table-2). The content of calcium in flower of $C$. decidua from Jhang, Layyah and Sarghodha (20.10, 32.91 and $13.30 \mathrm{mg} / 100 \mathrm{~g}$, respectively) was noted to be lower than that in fruit of $C$. decidua (21.50, 35.10 and $15.20 \mathrm{mg} / 100 \mathrm{~g}$ ), respectively.

The average contents $(23 \mathrm{mg} / 100 \mathrm{~g})$ of Caas determined in the present work was found to be lower as comparaed to those $(32.3 \mathrm{mg} / 100 \mathrm{~g})$ reported in fruits of $C$. decidua by Vyas et $a$. $^{24}$

Iron serves in metabolic and enzymatic functions e.g. synthesis of hemoglobin and iron containing enzyme which participate in electron transfer and redox reactions. According to WHO/UNICEF, iron deficiency is the most prevalent single nutritional deficiency in the world and is the main cause of anemia in infants, children, adolescents and women of child bearing age. Iron deficiency anemia is related to delayed cognitive development and intellectual impairment in children $^{27,28,30-31}$. Iron content in the flower and fruit of C. decidua from three different regions (Jhang, Layyah and Sarghodha) of Punjab was found to be 67.91-76.12 and 12.3-17.3 mg/100 $\mathrm{g}$, respectively (Table-2). Iron in flower from Jhang, Layyah and Sarghodha was noted to be higher than that in fruit samples of the same regions. The average content $(43.25 \mathrm{mg} / 100 \mathrm{~g})$ of iron as determined in the present work was found to be higher as comparable to $(34.26 \mathrm{mg} / 100 \mathrm{~g})$ that reported in flower of C. decidua from Fatehpur region of Rajasthan, India ${ }^{24}$.

Zinc plays an important role in biochemical, enzymatic, metabolic and physiological processes of the body. Deficiency of zinc may result in delayed sexual maturity, prolonged healing wounds, white spots on finger nails, decreased alertness, hair growth and susceptibility to infections ${ }^{32-33}$. The zinc content in the flower and fruit of $C$. decidua from three different regions (Jhang, Layyah and Sarghodha) of Punjab was established in the range of $0.22-0.27$ and $0.17-0.23 \mathrm{mg} / 100 \mathrm{~g}$, respectively. The zinc in flower from Jhang, Layyah and Sarghodha was noted to be $0.27,0.25$ and $0.22 \mathrm{mg} / 100 \mathrm{~g}$ higher than fruit of C. decidua $(0.23,0.20$ and $0.17 \mathrm{mg} / 100 \mathrm{~g})$ from the same regions. The combination of calcium and phosphorous is necessary for the formation of bones and teeth and nerve cells. It is component of DNA and RNA and of energy carrying enzymes $^{34,35}$.

Phosphorous content in the flower and fruits of C. decidua from three different regions (Jhang, Layyah and Sarghodha) of Punjab ranged from 426 to 550 and 701 to $807 \mathrm{mg} / 100 \mathrm{~g}$, respectively. The phosphorous in flower from the selected regions was noted to be $426-550 \mathrm{mg} / 100 \mathrm{~g}$ while in fruit 701 $807 \mathrm{mg} / 100 \mathrm{~g}$ showing significant $(p<0.05)$ variation among regions and between the parts tested. The average content $(626$ $\mathrm{mg} / 100 \mathrm{~g}$ ) of phosphorous in the two parts tested was found to be higher as comparaed to $(108-360 \mathrm{mg} / 100 \mathrm{~g})$ that reported by Vyas et al. $^{24}$.

\section{Conclusion}

The nutritional parameters and minerals content explored in flower and fruits of $C$. decidua from different regions of Punjab (Jhang, Layyah and Sarghodha) showed that flower and fruit of this species can be potetially used as valuable ingredients for human nutrition. The results further indicate that the flowers of $C$. decidua are good soure of zinc, iron, manganese and sodium whereas fruit of $C$. decidua are rich in phosphorous and potassium. Overall, proximate parameters and minerals composition of $C$. decidua varied slightly in relation to the parts tested while greatly among the regions studied.

\section{ACKNOWLEDGEMENTS}

The authors gratefully acknowledged the Department of Animal Nutrition, University of Agriculture, Faisalabad for providing some research facilities at their end.

\section{REFERENCES}

1. B. Joshi, G.P. Sah, B.B. Basnet, M.R. Bhatt, D. Sharma, K. Subedi, J. Pandey and R. Malla, J. Microbiol. Antimicrobiol., 3, 1 (2011).

2. B. Siahsar, M. Rahimi, A. Tavassoli and A.S. Raissi, Am.-Eurasian J. Agric. Environ. Sci., 11, 439 (2011).

3. A.S. Kamba and L.G. Hassan, I. J. Pharmacl. Fron. Res., 1, 32 (2011).

4. S. Ata, F. Farooq and S. Javed, J. Med. Plant Res., 5, 6164 (2011).

5. D. Hassawi and A. Kharma, J. Biol. Sci., 6, 109 (2006).

6. A. Mann, A. Banso and L.C. Clifford, J. Health. Res., 10, 34 (2008)

7. B. Mahesh and S. Satish, World J. Agric. Sci., 4, 83 (2008).

8. D.B. Milne, C.D. Davis and F.H. Nielsen, Nutrition, 17, 701 (2001).

9. K.O. Soetan, C.O. Olaiya and O.E. Oyewole, Afr. J. Food Sci., 4, 201 (2010). 
10. A. Aberoumand, Food Biol., 1, 3 (2011).

11. F. Chouhan, M.H.S. Wattoo, S.A. Tirmizi, F.Z. Memon, A.U. Rahman and M. Tufail, The Nucleus, 39, 196 (2002).

12. P. Singh, G. Mishra, S.S. Srivastava, K.K. Jha and R.L. Khosa, Der. Pharm. Lett., 3, 71 (2011).

13. H.R. Mahla, R.S. Mertia and N.K. Sinha, J. Med. Aroma. Plants, 1, 43 (2010).

14. B. Joseph and D. Jini, Res. J. Phytochem., 5, 1 (2011).

15. Association of Official Analytical Chemists (AOAC), Official Methods of Analysis of the Association of Official Analytical Chemists, Helrich, Washington, DC, edn. 15 (1990).

16. A. Sadzawka, M.A. Carrasco, R. Grez, M.L. Mora, H. Flores and A. Neaman, Instituto de Investigaciones Agropecuarias INIA, Santiago, Chile, Series Actas 34 (2006).

17. S.R. Thimmaiah, Kalyani Publishers, New Dehli, India, p. 80 (2004).

18. M.U. Dahot, J. Chem. Soc. Pak., 15, 79 (1993).

19. M.Z.U. Haq, S. Cavar, M. Qayum and I. Imranand V.d. Feo, Int. J. Mol. Sci., 12, 8848 (2011).

20. S.N. Chinedu, A.C. Olasumbo, O.K. Eboji, O.C. Emiloju, O.K. Arinola and D.I. Dania, Res. J. Chem. Sci., 1, 63 (2011).

21. S. Jongrungruangchok, S. Bunrathep and T. Songsak, J. Health Res., 24, 123 (2010).

22. D. Ahmed and M.A. Chaudhary, J. Appl. Sci. Res., 5, 865 (2009).
23. R.I. Bakare, O.A. Magbagbeola, A.I. Akinwande and O.W. Okunowo, J. Med. Plants Res., 4, 2191 (2010).

24. G.K. Vyas, R. Sharma, V. Kumar, T.B. Sharma and V. Khandelwal, Gen. Res. Crop Evol., 56, 905 (2009).

25. A. Aberoumand, Food Biol., 1, 3 (2011).

26. E.T. Friday, O. James, O. Olusegun and A. Gabriel, Int. J. Plant Physiol. Biochem., 3, 99 (2011).

27. G.E.O. Borgstahl, H.E. Parge, M.J. Hickey, W.F. Beyer Jr., R.A. Hallewell and J.A. Tainer, Cell, 71, 107 (1992).

28. S. Moscow and K. Jothivenkatachalam, Int. J. Pharm. Sci. Res., 3, 295 (2012).

29. K.D. Cashman, Br. J. Nutr., 87, 169 (2002).

30. L. Hulthen, Scand. J. Nutr., 47, 153 (2003).

31. S. Grantham-McGregor and C. Ani, J. Nutr., 131, 649 (2001).

32. O.M. El-Husseiny, M.O. Abd-Elsamee, I.I. Omara and A.M. Fouad, Int. J. Poul. Sci., 7, 757 (2008).

33. D. Bhowmik, K. Chiranjib and P.S. Kumar, Int. J. Pharm. Biomed. Sci., 1, 10 (2010).

34. Z. Ruan, Y.G. Zhang, Y.L. Yin,T.J. Li, R.L. Huang, S.W. Kim, G.Y. Wu and Z.Y. Deng, Asian-Aust. J. Anim. Sci., 20, 1236 (2007).

35. B.C. Sarker and J.L. Karmoker, Dhaka Univ. J. Biol. Sci., 20, 103 (2011). 